Waxin, Brewster, 2018. Public sector expatriation.

\title{
Public Sector Expatriation
}

\author{
Marie-France Waxin and Chris Brewster
}

Waxin, M.-F., Brewster, C. (2018) "Public sector expatriation" in Farazmand, Ali (ed.) Global Encyclopedia of Public Administration, Public Policy, and Governance. Springer International Publishing Switzerland.

First Online: 14 May 2016. DOI: https://doi.org/10.1007/978-3-319-20928-9 2568

Expatriation; International assignments

DOCUMENT ACCEPTED WITH MINOR MODIFICATIONS

\section{Definition}

A public sector expatriate is an employee who is sent abroad by their organization, for an organizational mission, for a precise period of time, and expected to return to their home organization, in their home country, after that time. When the assignment abroad lasts less than 1 year, we usually speak about short-term international assignment.

\section{Public Sector Expatriation}

Public sector organizations have a long tradition of sending personnel to other countries for a variety of purposes, such as diplomatic and military service (Groeneveld 2008). Indeed, they have been doing this as long as countries as such have existed - even before then rulers were sending their armies into other rulers' territories. Nowadays, the number of public servants working as expatriates (i.e., living and working outside their own countries for a time-determined period) seems to be continually increasing (Midura 2008).

Despite this long history, research attention to issues of expatriation and the problems of managing expatriates has been almost entirely conducted in the private sector among multinational companies (MNCs). Research on public sector expatriates and their unique working conditions is scarce (Fenner and Selmer 2008; Fisher et al., 2015; Green 2012; Groeneveld 2008; Selmer and Fenner 2009). The situation of expatriates in the public and private sector has both similarities and differences. There is a need for more attention to be paid to the situation in the public sector.

In this section of the encyclopedia, we:

Outline the different elements of the public sector that have expatriates.

Discuss the main differences between expatriation in the private and public sectors.

Outline some of the key issues in public sector expatriation.

Draw some conclusions.

\section{Different Parts of the Public Sector Using Expatriates}

Public servants who may get posted to other countries can be summarized under three main headings: 
Waxin, Brewster, 2018. Public sector expatriation.

(i) Government expatriates: armed services. Nearly all governments around the world have armed services pledged to defend the country against foreign enemies. This often involves active service in another country or spending time in another country as part of liaison with allies (Fisher et al. 2015). For the military, foreign postings are an integral part of their military career; they join expecting them to happen (DoA 2010). During a time of war, military personnel are generally unaccompanied by spouse/family when deployed and are rotated out of a combat setting every 12-18 months and returned home due to the psychological and physical demands of serving in an area under "hostile fire or imminent danger" (Fisher et al. 2015).

(ii). Government expatriates: diplomatic services. More common are the nonmilitary expatriates that the public sector sends to represent them in other countries or even to other organizations. These are generally referred to as the diplomatic service, although increasingly these include civil servants responsible for business, for science, or for public relations issues. For most, but not all, of these people too, service in another country is part of a normal career path and is expected.

(iii). Intergovernmental organizations. The third group of public sector expatriates are those who work for the intergovernmental organizations (IGOs) such as the United Nations, the European Union, or a wide variety of scientific and trade bodies run by numbers of countries jointly (Toomey and Brewster 2008). Some of these employees are seconded from their national governments' armed or civil service. Most are "self-initiated" expatriates (Suutari and Brewster 2000) who have applied to join one of these organizations from their own country and then started work at the Headquarters of an IGO or in one of its regional or national offices.

\section{Main Differences Between Expatriation in the Private and Public Sectors}

From this brief outline, it should be clear that there are a number of similarities and differences between public and private sector expatriates.

The similarities include the fact that all expatriates, from whatever sector, are spending time away from their base and their home country and living temporarily in another country. Both would normally take their nuclear family with them. Both tend to live in major cities where expatriates are common or in camps surrounded by other expatriates (Lauring and Selmer 2009). Common to both the private and public sector expatriate are the careful selection, the importance of preparation, the stress of moving, the need to adjust and perform in a foreign context, the uncertainty about the subsequent job, the challenging situation of partner and children (where families are involved), and the existence of rewards.

There are also key differences between public sector servant expatriates and private sector expatriates. For the private sector employees in MNCs, expatriation is sometimes a typical part of their work, if they are technical specialists, but is more often a one-off event and a significant factor marking them out as key "talents" with serious possibilities of moving up the career ladder (Cerdin and Brewster 2014). They will be generously rewarded for this unusual event. For relevant public sector expatriates, moving to another country is built into their contract and their pay and rewards are "international." Although they will receive significant emoluments for their time abroad, these are much lower than those available for private sector expatriates. Furthermore, these public sector expatriates are not 
Waxin, Brewster, 2018. Public sector expatriation.

moving from "home" to abroad - many of them (especially in the IGOs) are not based in their home country anyway. Many of the governmental expatriates are on regular rotations that means they may be at "home" for only brief periods in between assignments.

The rest of this section explores the issues that are peculiar to public sector expatriates, because of the nature of public sector work and employment. We follow the "expatriate cycle" (Waxin 2007) and consider recruitment and selection, the role of partners and families, location, preparation, adjustment, performance, rewards, and repatriation.

\section{Key Issues in Public Sector Expatriation}

\section{Recruitment and Selection}

Whereas in the private sector expatriates are usually selected from within the existing workforce, in the public sector expatriates are people who have signed up to a career that they know may involve international transfer. In all three parts of the public sector, employees are selected after careful screening and their contracts include an international mobility clause. Foreign assignments in the military are often of a multiple short-term character (Crowley-Henry and Heaslip 2014). In the diplomatic service, they are typically assignments of 3 or 4 years' duration. The different contractual arrangements between private and public sector expatriates mean that levels of commitment and motivation may differ (Fenner and Selmer 2008; Fisher et al. 2015; Selmer and Fenner 2009) in that public sector expatriates in effect select themselves for foreign postings in the course of applying for the job.

\section{Partners}

The frequent and regular moves involved in a foreign service career can be difficult for employees and particularly for their families (Fisher et al. 2015). As a result, some diplomatic services now include partners in the assignment decision (Green 2012; Groeneveld 2008). Moving to new postings is taxing for expatriates in many ways, including physiologically (Anderzen and Arnetz 1999), but is particularly challenging for partners, who do not have the continuity of a position to anchor them and who are often expected to handle the practical matters of life in a new and different culture, such as grocery shopping and making appointments (Family Liaison Office Department of State 2008). They are usually prevented from working in the new country as they find it hard to get work permits (Groeneveld 2008). In the case of military short-term international assignments, partners staying at home may be under serious stress (Crowley-Henry and Heaslip 2014), so more organizational support is needed.

\section{Location}

The extreme locational case is of course military expatriates who accept that their chosen career implies the possibility of relocation to dangerous and even life-threatening situations. Some members of the IGOs in the peacekeeping, refugee, food, and aid areas also find themselves in extremely risky situations; loss of life is all too frequent. For most of the diplomatic and IGO staff, dealing with local governments, their assignments are in more familiar big cities with related amenities. The culture of embassies, for example, may deliberately reflect the home country rather than the host country, 
Waxin, Brewster, 2018. Public sector expatriation.

offering a supportive environment for the expatriates (Johnson et al. 2002, 2003). In many postings, expatriates may to an extent be isolated from the "foreignness" of the country through housing, separate utilities, and the provision of home equipment (Family Liaison Office U.S. Department of State 2008; Green 2012). As a result, they may in some cases have little interaction with locals other than the country's educated, and often westernized, élite.

Military families know that they may get sent abroad again, but where will depend on the exigencies of national defense. The general rule in the diplomatic services is that service in an attractive location (e.g., a European capital) is followed by duty back home and then in a less attractive city or one in crisis (maybe in Africa) and then back home, followed by a move to a more attractive location. There are few such rules among the IGOs, most of which are based in very pleasant, safe cities, and some people manage to stay in pleasant locations their whole careers. However, there are many people in such organizations working "in the field," and those IGOs that work in difficult and dangerous situations attempt to rotate people between such locations and headquarters. There is a widespread demand from governments for these organizations to base more of their employees in a wider range of countries.

\section{Preparation}

The public sector is often better than the private sector in providing preparation for expatriates. Employees are often given additional training specific to the region to which they will be sent, including language training, cultural familiarity training, or political area studies (Honley 2005). The US Department of State, for example, offers several publications and classes to families with the aim of mitigating culture shock and maximizing successful adjustment (Green 2012). The US Department of Defense provides more extensive programs, although even here expatriates want more (Fenner and Selmer 2008).

\section{Adjustment}

Expatriates' adjustment to their new role and environment is of great significance, both to the organization and to the managers themselves (Waxin 2004, 2006). There is a lot of research on expatriate adjustment in the private sector even if much of it is limited in explanatory power (Haslberger et al. 2013). However, there is much less work on the adjustment of public sector expatriates (Green 2012). Expatriates never fully adjust: it depends on the nature and location of their assignment how far they will, but in all cases, they know that they will be leaving that country soon and while they may become competent and able to operate well in the environment, they are unlikely to change their general view of the world. In general, diplomatic and IGO expatriates seem to suffer from less stress than private sector expatriates. The isolation of some public sector expatriates noted above means that they may have less motivation and less need to adjust to the local environment. Nevertheless, they will have to adjust their behavior to some extent to be consistent with the local cultural values in order to avoid offending locals and to be able to operate effectively in the country (Shin et al. 2007).

\section{Performance}

Expatriate performance is less of an issue per se for public sector organizations than for private sector ones because as the transfer abroad is part of "normal" employment, there is little difference from everyday performance management. With little choice but to have such people (a diplomatic service or an intergovernmental aid organization could not act without expatriates), or with people operating 
Waxin, Brewster, 2018. Public sector expatriation.

in extreme conditions, and invariably with multiple and complex objectives, assessing performance is not easy. Mistakes, however, become very obvious and can have major consequences. "A higher weighting is assigned to the performance report of overseas service than to service at home" (Defense Force HRM report 2011).

\title{
Rewards
}

Expatriates from the public sector get a significantly enhanced salary for working abroad, though the enhancements are often noticeably less than those in the private sector. For example, expatriates from the US public sector have quarters allowances, post or hardship differentials, and danger pay. The "quarters allowances" cover housing costs at the foreign location when no government-provided quarters are available (U.S. Department of State 2015). "Post or hardship differentials" are additions to pay commensurate with the hardship of the post to which the employee is assigned: more sophisticated and westernized cities may have no such extras, whereas in dangerous or difficult countries, it may amount to anything up to a third or more of basic pay (U.S. Department of State, 2006a, para. 512). Some positions, where "civil insurrection, terrorism, or war conditions threaten physical harm or imminent danger," may also attract "danger pay" (U.S. Department of State 2006b, para. 652). In such cases, families would generally be expected to stay at home or in a nearby safe country.

\section{Repatriation}

Returning home may be a big problem in the private sector, but it is one that public sector employees do not face. For example, there is "a definite position in the organization for all military personnel, therefore alleviating any concerns that jobs in the home country may not be available in the organization on return from an assignment" (Crowley-Henry and Heaslip 2014).

\section{Conclusion}

Clearly there is a dearth of research into public sector expatriates. We need more information on the different types of international assignments in the public sector and more on how both short-term and long-term assignments are managed. There are millions of people working as public sector expatriates around the world. It seems that generally the management of expatriates in the public sector creates fewer problems than it does in the private sector, perhaps because expatriation is usually built into their contracts. Nevertheless, the difficulties that may arise as an expatriate and the difficulties in managing them are important and deserve greater attention.

\section{Cross-References}

\author{
Armed Forces \\ Diplomatic Staff \\ Expatriation \\ Human Resources Management \\ Intergovernmental Organizations \\ International Assignment
}


Waxin, Brewster, 2018. Public sector expatriation.

International Mobility

\section{References}

Anderzen I, Arnetz BB (1999) Psycho physiological reactions to international adjustment. Psychother Psychosom 68(2):67-75

Cerdin J-L, Brewster C (2014) Talent management and expatriation: bridging two streams of research and practice. J World Bus 49(2):245-252

Crowley-Henry M, Heaslip G (2014) Short-term international assignments. Military perspectives and implications for international human resource management. Eur Manag J 32:752-760

Defence Forces HRM Report (2011) Human resource management in the Irish defence forces 2011. The Department of Defence (Ireland)

DoA (Department of the Army) (2010) Assignments, details, and transfers: overseas service. Office of the Deputy Chief of Staff, Washington, DC. Retrieved from http://www.apd.army.mil/ pdffiles/r61430.pdf

Family Liaison Office, Department of State (2008) Spouse and partner guide to the Foreign service. Retrieved from http://www.state.gOv/documents/organization/101170.pdf

Fenner CR, Selmer J (2008) Public sector expatriate managers: psychological adjustment, personal characteristics and job factors. Int J Hum Resour Manag 19(7):1237-1252

Fisher K, Hutchings K, Pinto LH (2015) The lived acculturation experiences of US female military expatriates. Int J Intercult Relat 49:265-277

Green JM (2012) The relationship between adjustment and personal and work variables among American government employees and their spouses stationed abroad. Dissertation, Northcentral University, Graduate Faculty of the School of Behavioral and Health Sciences in Partial Doctor of Philosophy in Psychology, Prescott Valley

Groeneveld S (2008) Dual careers and diplomacy, the willingness of dual-career couples to accept an international assignment within the Dutch foreign service. Rev Public Pers Adm 28(1):20-43

Haslberger A, Brewster C, Hippler T (2013) The dimensions of expatriate adjustment. Hum Resour Manag 52(3):333-352

Honley SA (2005) Focus on FSI/FS training: FSI settles into Arlington Hall. Foreign Serv J JulAug:17-31

Johnson EC, Kristof-Brown AL, Van Vianen AEM, De Pater IE, Rigsby MM (2002) Expatriate social ties: the impact of relationships with comparable others and host country nationals. Academy of Management Proceedings and Membership Directory 08:pH1

Johnson EC, Kristof-Brown AL, Van Vianen AEM, De Pater IE, Klein MR (2003) Expatriate social ties: personality antecedents and consequences for adjustment. Int J Sel Assess 11(4):277-288

Lauring J, Selmer J (2009) Expatriate compound living: an ethnographic field study. Int J Hum Resour Manag 20(7):1451-1467

Midura KB (2008) Going it alone: family life in the "new" foreign service. Foreign Serv J 85(6):3035

Selmer J, Fenner CR (2009) Job factors and work outcomes of public sector expatriates. Hum Resour Manag J 19(1):75-90 
Waxin, Brewster, 2018. Public sector expatriation.

Shin SJ, Morgeson FP, Campion MA (2007) What you do depends on where you are: understanding how domestic and expatriate work requirements depend upon the cultural context. J Int Bus Stud 38(1):64-83

Suutari V, Brewster C (2000) Making their own way: international experience through self-initiated foreign assignments. J World Bus 35(4):417-436

Toomey E, Brewster C (2008) International HRM in International Organisations. In: Brewster C, Sparrow P, Dickmann M (eds) International human resource management: contemporary issues in Europe, 2nd edn. Routledge, London, pp 289-306

U.S. Department of State (2006a) Department of state standardized regulation 512. Retrieved from http://aoprals.state.gov/content.asp?content_id $=260 \&$ menu_id $=81$

U.S. Department of State (2006b) Department of state standardized regulation 652(g). Retrieved from http://aoprals.state.gov/content.asp?content_id=271\&menu_id=81

U.S. Department of State (2015) Quarterly report indexes of living costs abroad, quarters allowances, and hardship differentials, Oct 2015. Visited on 25 Nov 2015. https://aoprals.state.gov/ content.asp? content_id $=186 \&$ menu_id $=81$

Waxin M-F (2004) Expatriates' interaction adjustment: the direct and moderator effects of culture of origin. Int J Intercult Relat 28(1):61-79

Waxin M-F (2006) The effect of culture of origin on the adjustment process. In: Morley MJ, Heraty $\mathrm{N}$, Collings DG (eds) New directions in expatriate research. Palgrave MacMillan, New York, pp 120-141

Waxin M-F (2007) Chapter 12. "Strategic HRM Management of International Assignments". In: Katsioloudes M, Hadjidakis S (eds) International business. Elsevier, London, pp 387-438 